\title{
DCLK1 Expression in Colorectal Polyps Increases with the Severity of Dysplasia
}

\author{
AKI TAKIYAMA ${ }^{1}$, TOSHIAKI TANAKA ${ }^{1}$, SHINSUKE KAZAMA $^{2}$, HIROSHI NAGATA $^{1}$, KAZUSHIGE KAWAI ${ }^{1}$, \\ KEISUKE HATA $^{1}$, KENSUKE OTANI ${ }^{1}$, TAKESHI NISHIKAWA ${ }^{1}$, KAZUHITO SASAKI ${ }^{1}$, MANABU KANEKO ${ }^{1}$, \\ SHIGENOBU EMOTO $^{1}$, KOJI MURONO ${ }^{1}$, HIROTOSHI TAKIYAMA $^{1}$ and HIROAKI NOZAWA ${ }^{1}$ \\ ${ }^{1}$ Department of Surgical Oncology, The University of Tokyo, Tokyo, Japan; \\ ${ }^{2}$ Division of Gastroenterological Surgery, Saitama Cancer Center, Saitama, Japan
}

\begin{abstract}
Background: The expression of doublecortin-like kinase 1 (DCLK1) has been investigated in cancer; however not in precancerous adenomatous polyps. Materials and Methods: Immunohistological expression of DCLK1 was evaluated in various grades of adenomas, cancerous polyps, and hyperplastic polyps in resected human tissue specimens. Results: Ninety-two specimens were positive for DCLK1 and 134 were negative. Cancerous polyps showed a high DCLK1 positivity rate compared to adenomas (68.4\% vs. $36.8 \%$; $p<0.01)$. The rate of DCLK1 positivity was not significantly different among the three grades of adenomas (mild, moderate, and severe). DCLK1 was highly positive in advanced adenomas than low risk adenomas $49.6 \% \mathrm{vs}$. 29.3\%; p<0.01). Conclusion: The expression of DCLK1 was found in low-grade adenomas and increased with worsening severity of dysplasia. DCLK1 expression was highly observed in advanced adenomas, which had a clinically higher malignant potential.
\end{abstract}

Doublecortin-like kinase 1 (DCLK1) has been recognized as a possible marker for intestinal cancer stem cells (CSCs). Originally, it was known as a member of doublecortin family proteins, which are microtubule-associated kinases that regulate neuronal migration (1). Recently, DCLK1 has been reported to be overexpressed in several cancers, including lung (2), esophagus (3), pancreas $(4,5)$, kidney (6), breast

This article is freely accessible online.

Correspondence to: Aki Takiyama, Department of Surgical Oncology, The University of Tokyo, 7-3-1 Hongo, Bunkyo-ku, Tokyo 113-8655, Japan. Tel: +81 358008563, Fax: +81 338116822, e-mail: takiyamaa-sur@h.u-tokyo.ac.jp

Key Words: Cancer stem cell, colorectal adenoma, colorectal cancer, colorectal polyp, doublecortin-like kinase 1 .
(7), and colon (8-10). Previous research has postulated that DCLK1 expression is tightly associated with cancer growth, epithelial-to-mesenchymal transition (EMT), and tumor metastasis (11-18). In addition, high expression of DCLK1 has been reported to correlate with poor prognosis in human colorectal cancer (CRC) patients $(10,19,20)$.

Compared to leucine-rich repeat-containing G-protein coupled receptor 5 (LGR5) or CD133, which are known markers for both normal and tumor stem cells in the intestine $(21,22)$, DCLK1 is considered a marker of tumor stem cells, although it is also expressed by normal stem cells. (12). Therefore, several promising results on the use of DCLK1 as an anticancer therapeutic target have been reported (14, 23-25). Several studies have reported on the association of colorectal polyps with LGR5 $(22,26-30)$ and CD133 (3133). Takeda et al. suggested that the increase in the number of stem cells associated with LGR5 expression occurs early during colorectal tumorigenesis (26). Kazama et al. reported that CD133 expression is associated with status of differentiation and tumor size (33). Concerning DCLK1 expression in human colorectal polyps, there have been only a few reports. Gagliardi et al. (19) analyzed 18 adenomatous polyps and reported that staining score was not significantly associated with polyp location, size, morphology, architecture, degree of dysplasia, or the presence of carcinoma in situ. In contrast, Sarkar et al. (34) have reported that DCLK1 expression is stronger in both adenomas and adenocarcinomas than in normal colon mucosa, and moreover, it increases in the order of normal mucosa<adenomas<adenocarcinomas. In any case, both studies included only a small number of adenomas. Although DCLK1 is a good candidate therapeutic target, its expression in precancerous polyps or early cancerous lesions is unclear. In this study, we investigated DCLK1 expression in 226 polyps, including cancerous polyps (submucosal invasive carcinoma and carcinoma in situ), which were resected by colonoscopy. The aim was to clarify whether DLCK1 expression is correlated 
with the severity of dysplasia in colorectal adenomas. Correlations between the expression statuses of DCLK1 and prognosis of the patients were also analyzed.

\section{Materials and Methods}

Patient recruitment. A total of 226 available endoscopically-resected colorectal specimens were collected from 185 patients who underwent colonoscopy at the department of surgical oncology of the University of Tokyo our department from 1993 to 1996. All specimens were formalin-fixed and paraffin-embedded. Specimens with small size $(1 \mathrm{~mm})$ or not suitable for immunostaining were excluded.

Data on age, gender, survival information and location of the polyps were collected from the medical records of the patients. All specimens were examined histopathologically; adenomas were classified by the degree of dysplasia (mild, moderate, or severe), whereas cancerous polyps were classified by the depth of invasion (carcinoma in situ or submucosal invasive carcinoma), according to the Japanese Classification of Colorectal Carcinoma, 8th edition (35).

Advanced adenoma, described by Winawer et al. (36), is the most frequently used terminology to indicate adenomas with high potential for malignancy. Advanced adenoma is defined as an adenoma with at least one of the following three features: 1) the presence of villous features (more than 25\%), which is defined as a tubulovillous or villous adenoma according to WHO classification; 2) size of $1 \mathrm{~cm}$ or more; and 3) high-grade dysplasia or submucosal invasive carcinoma. We examined the polyps using this category. This study was approved by Tokyo University Hospital Ethics Committee. Written informed consent was obtained from all participants.

DCLK1 immunostaining. The tumor specimens fixed in $10 \%$ formalin solution, embedded in paraffin blocks, were cut into $4-\mu \mathrm{M}$ thick sections and immunohistochemically stained as previously described (10). The sections were incubated with primary antiDCLK1 rabbit polyclonal antibody (Ab31704, Abcam, Cambridge, MA, USA) in a 1:80 dilution overnight at $4^{\circ} \mathrm{C}$, after heat-induced antigen retrieval with an autoclave. The tissue sections were further incubated with the Dako Envision kit (Dako, Carpinteria, CA, USA), following the manufacturer's recommendations. Reactivity was visualized in $2 \% 3,3^{\prime}$-diaminobenzidine tetrahydrochloride and $50 \mathrm{mM}$ tris-buffer containing $0.3 \%$ hydrogen peroxidase.

Evaluation of DCLK1 immunostaining. Evaluation of immunostaining was performed as previously described (37). Staining intensity was categorized in four levels as follows: $0=$ none; $1=$ weak; $2=$ moderate; and $3=$ strong (Figure 1). The percentage of cells that were stained at each level was manually evaluated $(0 \%-100 \%)$. The cumulative percentage of the stained cells was calculated and multiplied by the staining intensity (range, 0-300). The cut-off value was determined as 20 by reference to evaluation criteria of Ikezono et al. (8). Analysis was performed independently and blindly by two observers (A.T. and H.T.) and any discrepancy was resolved by discussion. Subsequently, the correlation between DCLK1 expression and the clinicopathologic features of specimens/patients was analyzed.

Statistical analysis. The differences between the DCLK1 positive polyps and negative ones were analyzed by Chi-square test or Fisher's exact test for categorical variables, Student's $t$-test for normally distributed continuous variables, and Mann-Whitney $U$ -
Table I. Characteristics of the patients $(N=185)$ and colorectal polyps $(N=226)$.

\begin{tabular}{lcc}
\hline Patients & $\mathrm{n}$ & $\%$ \\
\hline Gender & & \\
Male & 149 & $(80.5)$ \\
Female & 36 & $(19.5)$ \\
& Median & Range \\
Age & 60 & $34-90$ \\
\hline Polyps & $\mathrm{n}$ & $\%$ \\
\hline Size & & \\
$<10$ mm & 110 & $(48.7)$ \\
$\geq 10$ mm & 116 & $(51.3)$ \\
Location & & \\
Right colon & 70 & $(31.0)$ \\
Left colon & 112 & $(49.5)$ \\
Rectum & 44 & $(19.5)$ \\
Histopathology & & \\
Hyperplastic polyp & 17 & $(7.5)$ \\
Adenoma with mild atypia & 17 & $(7.5)$ \\
Adenoma with moderate atypia & 126 & $(55.7)$ \\
Adenoma with severe atypia & 28 & $(12.4)$ \\
Carcinoma in situ & 27 & $(12.0)$ \\
Submucosal invasive carcinoma & 11 & $(4.9)$ \\
\hline
\end{tabular}

test for non-normally distributed continuous variables. Correlation of overall survival (OS) between patients with DCLK1-positive polyps and patients with DCLK1-negative polyps was analyzed by log-rank test.

All analyses were performed with the JMP v13.0 (SAS Institute Inc., Cary, NC, USA). Differences with a $p$-value $<0.05$ were considered statistically significant.

\section{Results}

Patient and polyp characteristics. The median age of patients was 60 years (range, $34-90$ years) and $80.6 \%$ were men. The characteristics of the polyps are shown in Table I. The size of the polyps ranged from 1 to $35 \mathrm{~mm} ; 51.3 \%$ of the polyps measured $\geq 10 \mathrm{~mm}$. The location was the right side of the colon (i.e., cecum, ascending colon, and transverse colon) in 70 specimens (31.4\%); the left side of the colon (i.e., descending and sigmoid colon) in 112 specimens (49.5\%); and the rectum in 44 specimens $(19.5 \%)$. Based on histopathologic evaluation, 11 polyps had submucosal invasion; 27 were carcinoma in situ; 28, 126, and 17 were adenomas with severe, moderate, and mild atypia, respectively, while 17 were hyperplastic polyps.

DCLK1 expression and clinicopathologic features. Among 226 specimens, 92 were positive and 134 were negative for DCLK1 (Table II). DCLK1 positivity rate was calculated for each histopathological category, and it increased in the following order: hyperplastic polyp (17.7\%); adenoma with 

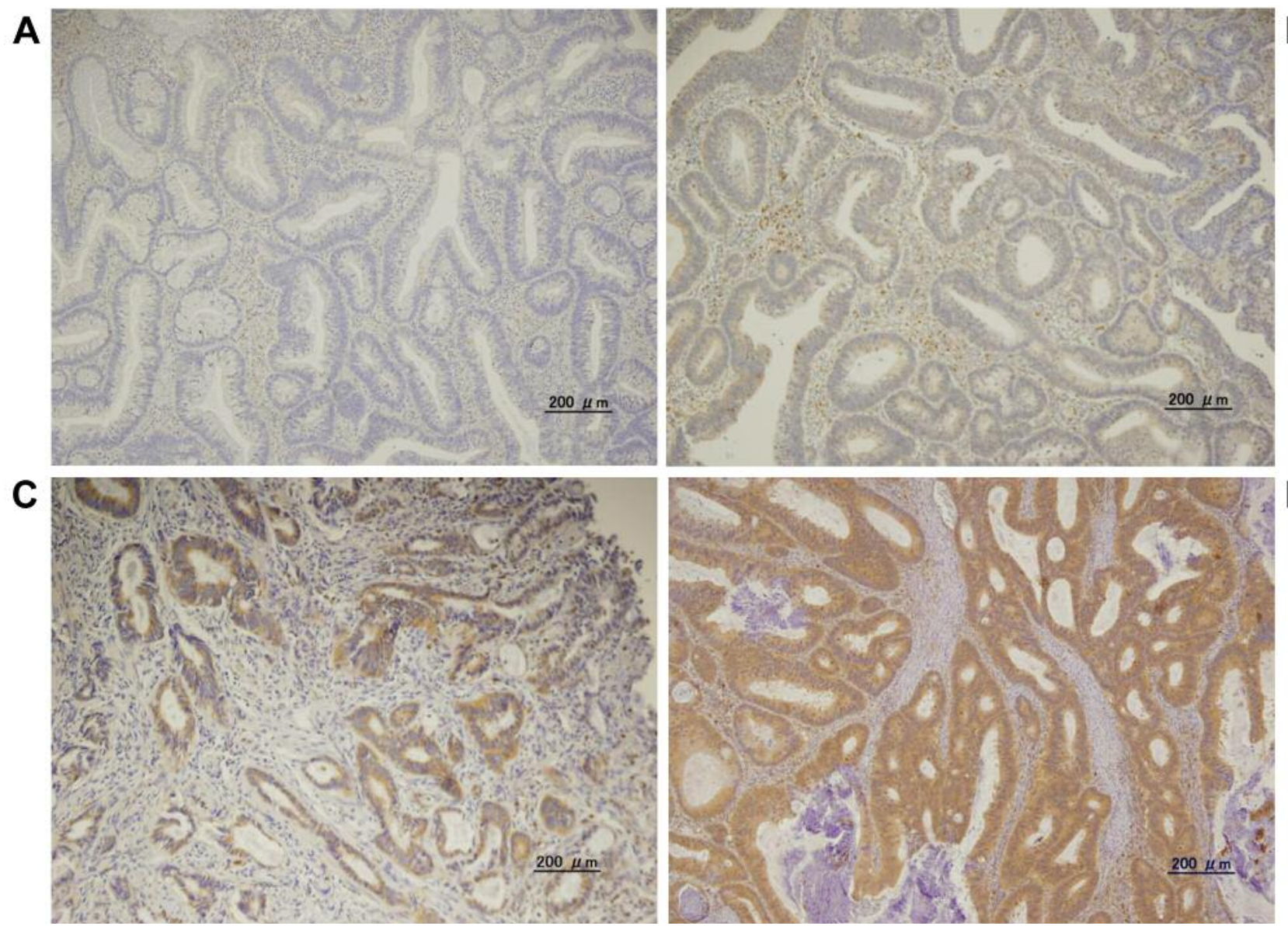

Figure 1. Immunohistochemical staining for DCLK1 in endoscopically-resected colorectal polyps. (A) score 0: no staining (original magnification $\times 100)$; $(B)$ score 1: weak (original magnification $\times 100)$; (C) score 2: moderate (original magnification $\times 100)$; (D) score 3: strong (original magnification $\times 100)$. DCLK1, Doublecortin-like kinase 1 .

mild atypia $(29.4 \%)$, moderate atypia $(35.7 \%)$, and severe atypia (46.4\%); carcinoma in situ (66.7\%); and submucosal invasive adenocarcinoma (72.7\%) (Figure 2). Cancerous polyps showed a high positive rate compared with adenomas (68.4\% vs. $36.8 \%, p<0.01)$. The rate of DCLK1 positivity was not significantly different among the three grades of adenomas (mild, moderate, and severe), but there was a tendency to increase with worsening severity of dysplasia (Figure 2).

Following the WHO classification (38), low-grade adenomas are those with mild and moderate dysplasia, whereas high-grade adenomas are those with severe dysplasia and carcinoma in situ. Using these definitions of severity, repeat analysis showed significant differences in DCLK1 positivity $(56.4 \%$ in high-grade adenomas vs. $35.0 \%$ in low-grade adenomas, $p<0.01)$.

DCLK1 expression in advanced adenomas. According to the criteria defined in Materials and Methods section, 123 of 209 specimens met the definition of advanced adenoma. DCLK1 expression was highly positive in advanced adenomas, but was rarely positive in non-advanced adenomas (49.6\% vs. $29.3 \%, p<0.01)$. Based on the classification by architecture, adenomas with villous features showed higher DCLK1 positivity than other polyps but it was not statistically significant $(62.5 \%$ vs. $39.0 \%, p=0.06)$. With regard to size, the rate of DCLK1 positivity was significantly higher in polyps $\geq 10 \mathrm{~mm}$ than in polyps $<10 \mathrm{~mm}(53.5 \% \mathrm{vs} .27 .3 \%$, $p<0.01)$. Similar to the results mentioned above, the group with high-grade adenomas or submucosal invasive carcinoma showed higher DCLK1 positive rate than the group with low-grade adenomas $(59.1 \%$ vs. $33.1 \%, p<0.01)$ (Table II).

OS of the patients. The 5-year OS of patients with DCLK1 positive polyps and patients with DCLK1 negative polyps were $100 \%$ and $98.4 \%$, respectively. No statistical significant difference was found between these two groups $(p=0.38)$. 


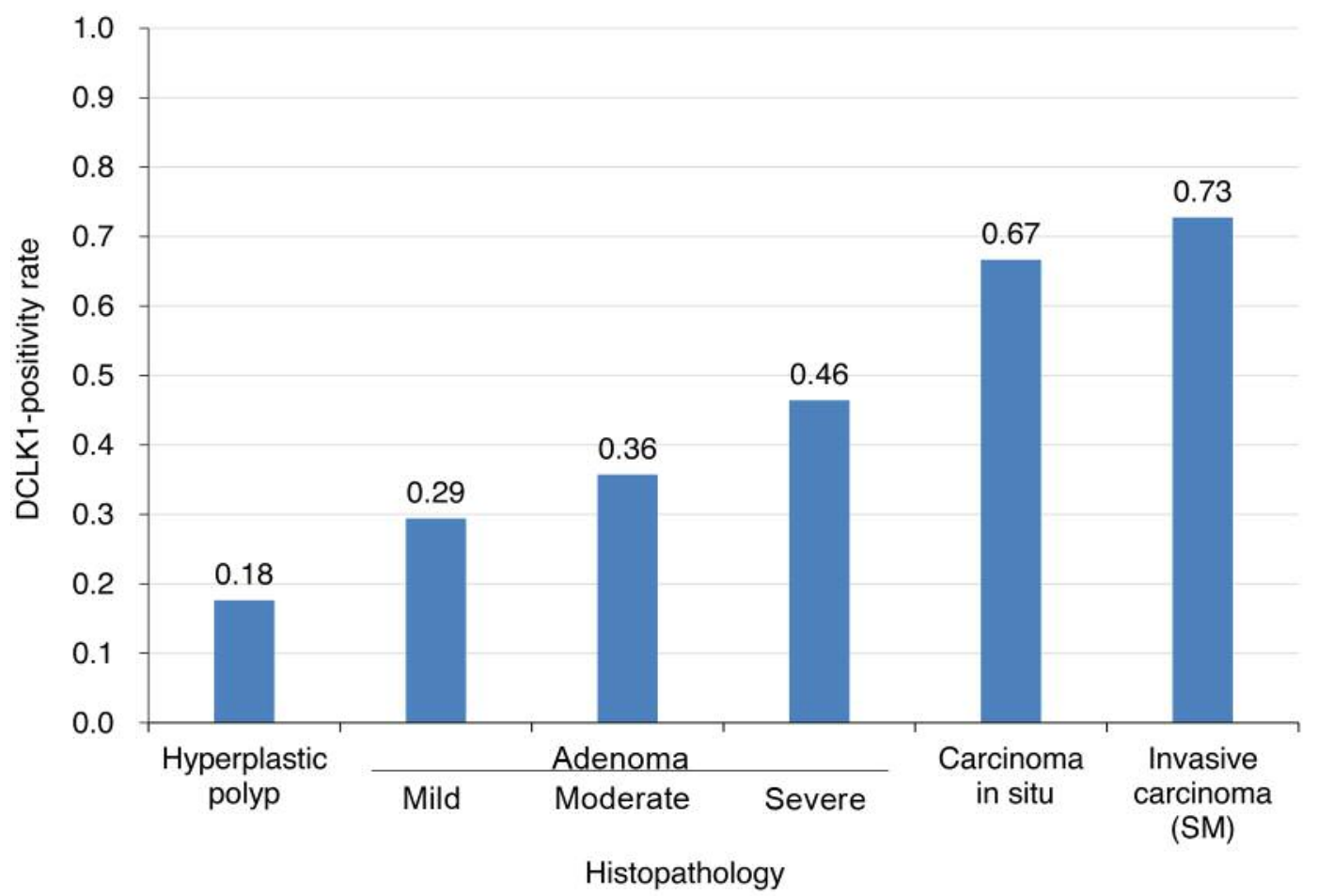

Figure 2. Rate of DCLK1-positivity for each histopathological category. The expression of DCLK1 was found in low-grade adenomas and increased with worsening severity of dysplasia. DCLK1, Doublecortin-like kinase 1; SM, submucosal.

Similar tendencies were shown in 10 -year OS $(96.2 \%$ and $95.9 \%$, respectively; $p=0.74)$ and 20 -year S $(92.0 \%$ and $75.6 \%$, respectively; $p=0.27$ ).

\section{Discussion}

In this study, DLCK1 expression was observed even in lowgrade adenomas and increased along with the increased severity of dysplasia. Furthermore, the highest expression of DLCK1 was found in carcinomas, consistent with the sequential process of carcinogenesis. The expression of DCLK1 was significantly higher in advanced adenomas, which are adenomas with a higher risk for malignancy.

In 2006, DCLK1 was first described as a stem cell marker in adult mouse gastric and small intestinal epithelial progenitors (39). Previously, DCLK1 expression in tumor tissue has been confirmed by many reports on mice with dextran sulfate sodium-induced colitis (23), which is an APC knockout model $(11,12)$, and on human colorectal cancers $(8,10,19)$. In a study on CRC metastasis, Gao et al. reported that DCLK1 expression was significantly increased in primary CRC and in lymphatic metastases compared with normal colorectal specimens, and moreover, DCLK1 mRNA levels in CRC were significantly correlated with lymph node metastasis and TNM stage (10). DCLK1 expression has also been strongly associated with EMT $(18,20)$. Although a number of genetic studies on DCLK1 have been reported, only few reports have investigated the behavior and distribution of DCLK1 expression in human CRC tissues.

For LGR5 expression, Takeda et al. (26) suggested the distribution of positive cells in a colorectal model; the location of LGR5 expression was at the base of crypts in normal epithelial cells, on the luminal surface in low-grade neoplasia, and on the bottom of the crypt and/or in invasive tumor front in high-grade neoplasia and adenocarcinoma. The presence of cancer stem cells on the tumor invasive front was suggested to correlate with metastasis and/or EMT. In a study on DCLK1 expression, Nakanishi et al. (12) observed DCLK1-positive cells at the base of the polyps in a murine model. Moreover, Ikezono et al. (8) presented a picture of DCLK1-positive cells on the invasive front of the mucosal layer in rectal neuroendocrine tumor. However, none of the studies focused on the changes in distribution of DCLK1 expression. In the present study, no statistical analysis of the distribution of DCLK1 expression in tissues was performed. Thus, whether the pattern of DCLK1 expression was similar (or not) to the previously reported distribution of LGR5 expression during each stage of 
Table II. DCLK1 expression in the colorectal polyps.

\begin{tabular}{|c|c|c|c|c|c|}
\hline \multirow{2}{*}{ Histopathology } & \multicolumn{2}{|c|}{$\begin{array}{c}\text { Positive for DCLK1 } \\
\text { (\% of total positive samples) }\end{array}$} & \multicolumn{2}{|c|}{$\begin{array}{c}\text { Negative for DCLK1 } \\
\text { (\% of total negative samples) }\end{array}$} & \multirow[t]{2}{*}{$p$-Value } \\
\hline & & & & & \\
\hline Hyperplastic & 3 & $(3.2 \%)$ & 14 & $(10.4 \%)$ & \\
\hline Adenoma & 63 & $(68.5 \%)$ & 108 & $(80.6 \%)$ & \\
\hline Cancerous & 26 & $(28.3 \%)$ & 12 & $(9.0 \%)$ & $<0.001$ \\
\hline \multicolumn{6}{|l|}{ Adenoma (grade) } \\
\hline Adenoma with mild atypia & 5 & $(8.0 \%)$ & 12 & $(11.1 \%)$ & \\
\hline Adenoma with moderate atypia & 45 & $(71.4 \%)$ & 81 & $(75.0 \%)$ & \\
\hline Adenoma with severe atypia & 13 & $(20.6 \%)$ & 15 & $(13.9 \%)$ & 0.45 \\
\hline \multicolumn{6}{|l|}{ Cancerous } \\
\hline Carcinoma in situ & 18 & $(69.2 \%)$ & 9 & $(75.0 \%)$ & \\
\hline Submucosal invasive carcinoma & 8 & $(30.8 \%)$ & 3 & $(25.0 \%)$ & 1.00 \\
\hline \multicolumn{6}{|l|}{ Advanced adenoma or not } \\
\hline Advanced adenoma & 63 & $(68.5 \%)$ & 64 & $(47.8 \%)$ & \\
\hline Non-advanced adenoma & 29 & $(31.5 \%)$ & 70 & $(52.2 \%)$ & $<0.01$ \\
\hline \multicolumn{6}{|l|}{ Criteria of advanced adenoma } \\
\hline \multicolumn{6}{|l|}{ Architecture } \\
\hline Adenoma with villous features & 10 & $(10.9 \%)$ & 6 & $(4.5 \%)$ & 0.06 \\
\hline Without villous features & 82 & $(89.1 \%)$ & 128 & $(95.5 \%)$ & \\
\hline \multicolumn{6}{|l|}{ Size } \\
\hline$<1 \mathrm{~cm}$ & 30 & $(32.6 \%)$ & 80 & $(59.7 \%)$ & \\
\hline$\geq 1 \mathrm{~cm}$ & 62 & $(67.4 \%)$ & 54 & $(40.3 \%)$ & $<0.001$ \\
\hline \multicolumn{6}{|l|}{ Grade of adenoma } \\
\hline High-grade adenoma+submucosal invasive carcinoma & 39 & $(42.4 \%)$ & 27 & $(20.1 \%)$ & \\
\hline others & 53 & $(57.6 \%)$ & 107 & $(79.9 \%)$ & $<0.001$ \\
\hline
\end{tabular}

DCLK1, Doublecortin-like kinase 1.

colorectal carcinogenesis remains unclear. Further studies are needed to investigate the distribution of DCLK1 expression according to the stage of colorectal carcinogenesis.

DCLK1 has also been examined as an anticancer therapeutic target. The findings with the most impact were reported by Nakanishi et al. (12), who showed that ablation of DCLK1 in murine models resulted in tumor shrinkage without damage to the normal intestine. In contrast, selective ablation of LGR5positive cells did not lead to tumor regression and the presence of proliferative LGR5-negative cells on tumors persisted in a murine model (40). For the association of CD133 with CRC treatment, several studies have reported that CD133-positive CRC might be resistant to chemotherapy or chemoradiotherapy (41-43). Moreover, CD133-targeted oncolytic measles virus has been shown to specifically eliminate CD133-positive tumor cells (glioblastoma and hepatocellular carcinoma) in a murine model (44); however, fatal neurotoxicity was developed in this model. Based on these studies, DCLK1 seems to be the most promising target for CRC treatment, at present. Our results support the idea that therapeutic methods targeted to DCLK1 might not only affect CRC, but also cancerous and precancerous polyps. This new therapeutic approach may reduce the use of invasive methods, such as surgery and endoscopic resection, in CRC treatment.
There were several limitations to this study. The number of specimens evaluated was relatively small for this retrospective study and there might have been biases during patient recruitment. Some information about the past history of polyps and other diseases of the intestine, as well as family history, was lacking and not evaluated. In addition, the preceding studies about DCLK1 immunostaining are few and there has been no consensus on their evaluation criteria. Although the evaluation criteria adopted in this study were rather arbitrary, we hope that these would be of assistance to subsequent researchers.

\section{Conclusion}

The expression of DCLK1, which is a possible cancer stem cell marker, was found in low-grade adenomas and increased with worsening severity of dysplasia. It was also highly observed in advanced adenomas, which have a higher malignant potential.

\section{Acknowledgements}

This research is supported by Grants-in-Aid for Scientific Research (A: grant number;16H02672, C: grant number;16K07143, C: grant number;16K07161, C: grant number; 17K10620, C: grant number;17K10621 and C: grant number;17K10623) from Japan 
Society for the promotion of Science. This research is supported by the Project for Cancer Research and Therapeutic Evolution (PCREATE, grant number: $16 \mathrm{~cm} 0106502 \mathrm{~h} 0001)$ from the Japan Agency for Medical Research and Development (AMED).

\section{References}

1 Burgess HA, Martinez S and Reiner O: Kiaa0369, doublecortinlike kinase, is expressed during brain development. J Neurosci Res 58(4): 567-575, 1999.

2 Tao H, Tanaka T and Okabe K: Doublecortin and cam kinaselike-1 expression in pathological stage i non-small cell lung cancer. J Cancer Res Clin Oncol 143(8): 1449-1459, 2017.

3 Vega KJ, May R, Sureban SM, Lightfoot SA, Qu D, Reed A, Weygant N, Ramanujam R, Souza R, Madhoun M, Whorton J, Anant S, Meltzer SJ and Houchen CW: Identification of the putative intestinal stem cell marker doublecortin and cam kinaselike-1 in barrett's esophagus and esophageal adenocarcinoma. J Gastroenterol Hepatol 27(4): 773-780, 2012.

4 Ikezono Y, Koga H, Akiba J, Abe M, Yoshida T, Wada F, Nakamura T, Iwamoto H, Masuda A, Sakaue T, Yano H, Tsuruta $\mathrm{O}$ and Torimura T: Pancreatic neuroendocrine tumors and emt behavior are driven by the csc marker dclk1. Mol Cancer Res 5(6): 744-752, 2017.

5 Ito $\mathrm{H}$, Tanaka $\mathrm{S}$, Akiyama $\mathrm{Y}$, Shimada S, Adikrisna R, Matsumura S, Aihara A, Mitsunori Y, Ban D, Ochiai T, Kudo A, Arii S, Yamaoka S and Tanabe M: Dominant expression of dclk1 in human pancreatic cancer stem cells accelerates tumor invasion and metastasis. PLoS One 11(1): e0146564, 2016.

6 Weygant N, Qu D, May R, Tierney RM, Berry WL, Zhao L, Agarwal S, Chandrakesan P, Chinthalapally HR, Murphy NT, Li JD, Sureban SM, Schlosser MJ, Tomasek JJ and Houchen CW: Dclk1 is a broadly dysregulated target against epithelialmesenchymal transition, focal adhesion, and stemness in clear cell renal carcinoma. Oncotarget 6(4): 2193-2205, 2015.

7 Liu YH, Tsang JY, Ni YB, Hlaing T, Chan SK, Chan KF, Ko CW, Mujtaba SS and Tse GM: Doublecortin-like kinase 1 expression associates with breast cancer with neuroendocrine differentiation. Oncotarget 7(2): 1464-1476, 2016.

8 Ikezono YU, Koga H, Abe M, Akiba J, Kawahara A, Yoshida T, Nakamura T, Iwamoto H, Yano H, Kage M, Sata M, Tsuruta O and Torimura T: High expression of the putative cancer stem cell marker, dclk1, in rectal neuroendocrine tumors. Oncol Lett 10(4): 2015-2020, 2015.

9 Gagliardi G, Moroz K and Bellows CF: Immunolocalization of dcamkl-1, a putative intestinal stem cell marker, in normal colonic tissue. Pathol Res Pract 208(8): 475-479, 2012.

10 Gao T, Wang M, Xu L, Wen T, Liu J and An G: Dclk1 is upregulated and associated with metastasis and prognosis in colorectal cancer. J Cancer Res Clin Oncol 142(10): 2131-2140, 2016.

11 May R, Riehl TE, Hunt C, Sureban SM, Anant S and Houchen $\mathrm{CW}$ : Identification of a novel putative gastrointestinal stem cell and adenoma stem cell marker, doublecortin and cam kinaselike-1, following radiation injury and in adenomatous polyposis coli/multiple intestinal neoplasia mice. Stem Cells 26(3): 630637, 2008.

12 Nakanishi Y, Seno H, Fukuoka A, Ueo T, Yamaga Y, Maruno T, Nakanishi N, Kanda K, Komekado H, Kawada M, Isomura A, Kawada K, Sakai Y, Yanagita M, Kageyama R, Kawaguchi Y, Taketo MM, Yonehara S and Chiba T: Dclk1 distinguishes between tumor and normal stem cells in the intestine. Nat Genet 45(1): 98-103, 2013.

13 Bailey JM, Alsina J, Rasheed ZA, McAllister FM, Fu YY, Plentz R, Zhang H, Pasricha PJ, Bardeesy N, Matsui W, Maitra A and Leach SD: Dclk1 marks a morphologically distinct subpopulation of cells with stem cell properties in preinvasive pancreatic cancer. Gastroenterology 146(1): 245-256, 2014.

14 Weygant N, Qu D, Berry WL, May R, Chandrakesan P, Owen DB, Sureban SM, Ali N, Janknecht R and Houchen CW: Small molecule kinase inhibitor lrrk2-in-1 demonstrates potent activity against colorectal and pancreatic cancer through inhibition of doublecortin-like kinase 1. Mol Cancer 13: 103, 2014.

15 Sureban SM, May R, Weygant N, Qu D, Chandrakesan P, Bannerman-Menson E, Ali N, Pantazis P, Westphalen CB, Wang TC and Houchen CW: Xmd8-92 inhibits pancreatic tumor xenograft growth via a dclk1-dependent mechanism. Cancer Lett 351(1): 151-161, 2014.

16 Chandrakesan P, Weygant N, May R, Qu D, Chinthalapally HR, Sureban SM, Ali N, Lightfoot SA, Umar S and Houchen CW: Dclk1 facilitates intestinal tumor growth via enhancing pluripotency and epithelial mesenchymal transition. Oncotarget 5(19): 9269-9280, 2014.

17 Chandrakesan P, Panneerselvam J, Qu D, Weygant N, May R, Bronze MS and Houchen CW: Regulatory roles of dclk1 in epithelial mesenchymal transition and cancer stem cells. J Carcinog Mutagen 7(2): pii: 257, 2016.

18 Chandrakesan P, Yao J, Qu D, May R, Weygant N, Ge Y, Ali N, Sureban SM, Gude M, Vega K, Bannerman-Menson E, Xia L, Bronze M, An G and Houchen CW: Dclk1, a tumor stem cell marker, regulates pro-survival signaling and self-renewal of intestinal tumor cells. Mol Cancer 16(1): 30, 2017.

19 Gagliardi G, Goswami M, Passera R and Bellows CF: Dclk1 immunoreactivity in colorectal neoplasia. Clin Exp Gastroenterol 5: 35-42, 2012.

20 Chandrakesan P, May R, Weygant N, Qu D, Berry WL, Sureban SM, Ali N, Rao C, Huycke M, Bronze MS and Houchen CW: Intestinal tuft cells regulate the atm mediated DNA damage response via dclk1 dependent mechanism for crypt restitution following radiation injury. Sci Rep 6: 37667, 2016.

21 Yu X, Lin Y, Yan X, Tian Q, Li L and Lin EH: Cd133, stem cells, and cancer stem cells: Myth or reality? Curr Colorectal Cancer Rep 7(4): 253-259, 2011.

22 Becker L, Huang Q and Mashimo H: Immunostaining of lgr5, an intestinal stem cell marker, in normal and premalignant human gastrointestinal tissue. Scientific World Journal 8: 1168-1176, 2008.

23 Qu D, Weygant N, May R, Chandrakesan P, Madhoun M, Ali N, Sureban SM, An G, Schlosser MJ and Houchen CW: Ablation of doublecortin-like kinase 1 in the colonic epithelium exacerbates dextran sulfate sodium-induced colitis. PLoS One 10(8): e0134212, 2015.

24 Westphalen CB, Asfaha S, Hayakawa Y, Takemoto Y, Lukin DJ, Nuber AH, Brandtner A, Setlik W, Remotti H, Muley A, Chen X, May R, Houchen CW, Fox JG, Gershon MD, Quante M and Wang TC: Long-lived intestinal tuft cells serve as colon cancerinitiating cells. J Clin Invest 124(3): 1283-1295, 2014.

25 Sureban SM, May R, Mondalek FG, Qu D, Ponnurangam S, Pantazis P, Anant S, Ramanujam RP and Houchen CW: Nanoparticle-based delivery of sidcamkl-1 increases microrna144 and inhibits colorectal cancer tumor growth via a notch-1 dependent mechanism. J Nanobiotechnology 9: 40, 2011. 
26 Takeda K, Kinoshita I, Shimizu Y, Matsuno Y, Shichinohe T and Dosaka-Akita H: Expression of lgr5, an intestinal stem cell marker, during each stage of colorectal tumorigenesis. Anticancer Res 31(1): 263-270, 2011.

27 Choi JW, Kim JK, Choi M, Kim YR and Yun SH: In vivo imaging of lgr5-positive cell populations using confocal laser endomicroscopy during early colon tumorigenesis. Endoscopy 46(12): 1110-1116, 2014.

28 Drew JE, Farquharson AJ, Mayer CD, Vase HF, Coates PJ, Steele RJ and Carey FA: Predictive gene signatures: Molecular markers distinguishing colon adenomatous polyp and carcinoma PLoS One 9(11): e113071, 2014.

29 Baker AM, Graham TA, Elia G, Wright NA and Rodriguez-Justo M: Characterization of lgr5 stem cells in colorectal adenomas and carcinomas. Sci Rep 5: 8654, 2015.

30 Jang BG, Kim HS, Kim KJ, Rhee YY, Kim WH and Kang GH: Distribution of intestinal stem cell markers in colorectal precancerous lesions. Histopathology 68(4): 567-577, 2016.

31 Mohammadi M, Bzorek M, Bonde JH, Nielsen HJ and Holck S: The stem cell marker cd133 is highly expressed in sessile serrated adenoma and its borderline variant compared with hyperplastic polyp. J Clin Pathol 66(5): 403-408, 2013.

32 Yang CY, Tseng JY, Chen CF, Chou TY, Gao HW, Hua CL, Lin $\mathrm{CH}$, Lin JK and Jiang JK: Genome-wide copy number changes and cd133 expression characterized distinct subset of colon polyps: Differentiation between incidental polyps and cancerassociated polyps. Int J Colorectal Dis 30(12): 1617-1626, 2015

33 Kazama S, Kishikawa J, Kiyomatsu T, Kawai K, Nozawa H, Ishihara $\mathrm{S}$ and Watanabe $\mathrm{T}$ : Expression of the stem cell marker cd133 is related to tumor development in colorectal carcinogenesis. Asian J Surg, 2017.

34 Sarkar S, Popov VL, O'Connell MR, Stevenson HL, Lee BS, Obeid RA, Luthra GK and Singh P: A novel antibody against cancer stem cell biomarker, dclk1-s, is potentially useful for assessing colon cancer risk after screening colonoscopy. Lab Invest 97(10): 1245-1261, 2017.

35 Japanese Society for Cancer of the Colon and Rectum (2013): Japanese classification of colorectal carcinoma. The 8th edition. Kanehara \& CO, LTD Tokyo, 2013.

36 Winawer SJ and Zauber AG: The advanced adenoma as the primary target of screening. Gastrointest Endosc Clin N Am 12(1): 1-9, v, 2002.

37 Detre S, Saclani Jotti G and Dowsett M: A "quickscore" method for immunohistochemical semiquantitation: Validation for oestrogen receptor in breast carcinomas. J Clin Pathol 48(9): 876-878, 1995.
38 Bosman FT, World Health Organization and International Agency for Research on Cancer: WHO classification of tumours of the digestive system. 4th ed. Lyon, International Agency for Research on Cancer, 2010.

39 Giannakis M, Stappenbeck TS, Mills JC, Leip DG, Lovett M, Clifton SW, Ippolito JE, Glasscock JI, Arumugam M, Brent MR and Gordon JI: Molecular properties of adult mouse gastric and intestinal epithelial progenitors in their niches. J Biol Chem 281(16): 11292-11300, 2006.

40 de Sousa e Melo F, Kurtova AV, Harnoss JM, Kljavin N, Hoeck JD, Hung J, Anderson JE, Storm EE, Modrusan Z, Koeppen H, Dijkgraaf GJ, Piskol R and de Sauvage FJ: A distinct role for lgr5+ stem cells in primary and metastatic colon cancer. Nature 543(7647): 676-680, 2017.

41 Saigusa S, Tanaka K, Toiyama Y, Yokoe T, Okugawa Y, Kawamoto A, Yasuda H, Morimoto Y, Fujikawa H, Inoue Y, Miki $\mathrm{C}$ and Kusunoki M: Immunohistochemical features of cd133 expression: Association with resistance to chemoradiotherapy in rectal cancer. Oncol Rep 24(2): 345-350, 2010.

42 Hongo K, Kazama S, Sunami E, Tsuno NH, Takahashi K, Nagawa $\mathrm{H}$ and Kitayama J: Immunohistochemical detection of cd133 is associated with tumor regression grade after chemoradiotherapy in rectal cancer. Med Oncol 29(4): 2849$2857,2012$.

43 Ong CW, Kim LG, Kong HH, Low LY, Iacopetta B, Soong R and Salto-Tellez M: Cd133 expression predicts for non-response to chemotherapy in colorectal cancer. Mod Pathol 23(3): 450457, 2010.

44 Kleinlutzum D, Hanauer JDS, Muik A, Hanschmann KM, Kays SK, Ayala-Breton C, Peng KW, Muhlebach MD, Abel T and Buchholz CJ: Enhancing the oncolytic activity of cd133-targeted measles virus: Receptor extension or chimerism with vesicular stomatitis virus are most effective. Front Oncol 7: 127, 2017.

Received November 13, 2017

Revised January 29, 2018

Accepted January 30, 2018 